\title{
Permakultura a její inspirace pro oblast společného (inkluzivního) vzdělávání
}

\section{Monika Janáková}

Envigogika 16 (2) - Inspirace/Inspiration

Published/ Publikováno 8. 12. 2021

DOI: $\underline{10.14712 / 18023061.630}$

\begin{abstract}
Abstrakt
Text je kratším zamyšlením nad podněty, které může přinést permakultura do inkluzivního vzdělávání. Rozvíjí myšlenku různorodosti, která se projevuje na úrovni druhů, pohledů a př́stupů, nebo funkcí. Tato diverzita přispívá ke stabilitě celku.
\end{abstract}

\section{Klíčová slova}

Permakultura; vzdělávání; inkluze; prvek; systém; celek

\begin{abstract}
The text is a shorter reflection on the inspirations that permaculture can bring to inclusive education. It works with the idea of diversity, which manifests itself at the level of species, views and approaches, or functions. This diversity contributes to the stability of the whole.
\end{abstract}

\section{Key words}

Permaculture; education; inclusion; element; system; whole 


\section{Úvod}

Následující text je kratším zamyšlením nad podněty, které může přinést permakultura do inkluzivního vzdělávání. Jeho autorka vychází ze základní permakulturní literatury, svých úvah a postřehů a výsledků projektu Children in Pemaculture. Chce ukázat, že permakultura je, už ze své podstaty, výrazně inkluzivní. Klade důraz na význam různorodosti prvků v rámci systému (at́ už se jedná o ekosystém, nebo lidskou společnost) a okrajových jevů - pokládá je za místa, kde často vznikají nové situace a řešení ovlivňující chod systému a jeho vývoj často výrazněji, než uniformní standardizované a navzájem si silně podobné prvky v jeho centru.

\section{Permakultura a její pravidla}

Permakultura upozorňuje na to, že různorodé prvky a okrajové systémy často přináší informace a podněty důležité $k$ sebereflexi celého systému, jež mohou vyžadovat tvưrčí řešení v dané situaci; na závěr pak může dojít k posunutí vývoje systému jako celku.

Důraz na zahrnutí (inkluzi) těchto "okrajů" vyplývá také ze samotného fundamentu permakultury, kterým jsou tzv. tři etická permakulturní pravidla. ${ }^{1}$ Těmi jsou péče o zemi, péče o lidi, omezení populace a spotřeby. Zejména péče o lidi je pravidlem, které je nutné $v$ souvislosti s inkluzí uvést. Znamená pečovat nejen o sebe jako jedince, ale také o druhé, vnímat a zohledňovat jejich potřeby při svém každodenním jednání. Zde je kladen důraz na potřeby nejen dětí, ale také pedagogů a rodičů. $V$ rámci výchovy klade permakultura důraz na spolupráci místo konkurenčního boje, empatii, otevřenou komunikaci, pohodu všech součástí daného systému vzdělávání (skupiny, třídy, atd.), což pak obecně vede k inkluzivnímu způsobu myšlení.

Permakultura zdůrazňuje právě tento typ myšlení, který rozvíjí samostatnost a schopnost tvůrčího myšlení a řešení problémů, a má prostupovat naším každodenním konáním. Vyzdvihuje různorodost a její vnímání jako něco, co není třeba přizpůsobovat násilně do standardizované podoby. Tato různorodost je naopak př́nosem, impulsem vedoucím často $\mathrm{k}$ posunu v myšlení, k zájmu o nové informace, nové zážitky; tyto podněty jsou využitelné jako inspirace pro chod celého systému.

Podobně i druhé permakulturní pravidlo zdůrazňující spravedlivé dělení poukazuje na význam toho, že potlačíme negativní postoj k různosti. Je snahou o rovnost mezi lidmi bez ohledu na fyzické handicapy, barvu pleti, pohlaví, zemi atd. Všem se má v rámci spravedlivého dělení dostat stejné pozornosti, stejných př́ležitostí. Možnost fungovat v daném systému tak, aby všichni byli spokojeni, št́astni a vnímali podporu svým činnostem.

Jak bylo již řečeno, spravedlivé dělení bývá užíváno v permakultuře taktéž ve významu „přerozdělování přebytkư" (Holmgren, 2002) - toto pravidlo hovoří o citlivosti a nastavení hranic toho, kolik si bereme pro sebe ze systému a kolik do něj vracíme zpět $v$ rámci péče o Zemi i o lidi. Některým dětem se daří být v centru systému z důvodu sociálního postavení rodičů, nebo země ve které se narodily a podobně. Mají plné podmínky pro svůj rozvoj. Přerozdělování přebytků ve formě komfortu a výdobytků konzumní společnosti má cílit na podporu dětí, které tyto výhody nemají, a směřovat $\mathrm{k}$ jejich inkluzi do systému celé společnosti. Toto přerozdělování v rámci systému není pouhou charitou, dobročinností, která je sice milá, ale dlouhodobě stejně neefektivní. Naopak, v duchu permakultury je třeba brát v potaz, že hladké fungování systému je zajištěno správným začleněním jeho prvků. To podporuje jeho

\footnotetext{
${ }^{1}$ zde Ize ovšem namítnout, že by spíše měl být používán termín „morální pravidla", nežli etická.
} 
udržitelnost, což je další z klíčových pojmů permakultury. Pakliže dokážeme v rámci pedagogiky takto uvažovat a vnímat, že skrze inkluzi přispíváme nejen ke spokojenosti a štěstí daného jednotlivce, dítěte, ale že tím vlastně budujeme dlouhodobou udržitelnost celé společnosti jako systému, nemůžeme než přitakat inkluzi jako dlouhodobě důležitému, a nejen módnímu, tématu.

\section{Permakulturní principy podporující inkluzi}

Co se týče obecného vztahu permakultury k inkluzi, můžeme poukázat na konkrétní permakulturní principy podporující myšlenku začleňování. Zde uved'me princip „Dej přednost začleňování před oddělováním". Tento princip upozorňuje, že $v$ přírodě jsou vztahy mezi věcmi stejně důležité jako věci samotné. Celek je pro permakulturu více než pouhý součet jeho částí. To nás vede $\mathrm{k}$ tomu, abychom se snažili najít vhodné místo pro každou část, abychom tvořili podpůrné a spolupracující vztahy. $V$ zahradě to může znamenat vysadit vedle sebe rostliny, které prospívají lépe ve vzájemné blízkosti než samostatně. Při hodině s dětmi můžeme využít tento princip ve snaze o zapojení každého dítěte do skupiny tak, aby se doplňovaly svými schopnostmi a zájmy, aby byla vyzdviženy a funkčně uplatněny přednosti dítěte, to, čím jsou výrazné. Pokud klademe důraz na to, že vše a každý je důležitý a má své zvláštní místo a roli, předcházíme vyloučení něčeho nebo někoho, a podporujeme myšlenku inkluze.

Další z permakulturních principů „Každý prvek má více funkcí a každá funkce je zajištována mnoha prvky" také svojí podstatou podporuje myšlenku inkluze. Př́kladem prvků může být strom, dítě nebo rybník, a funkcí je to, co daný prvek poskytuje. Všechny funkce každého prvku jsou důležité, at již jsou v daný okamžik potřeba či ne. Neexistují žádné méně důležité, vedlejší funkce. Např. strom tvoří kyslík, zároveň poskytuje úkryt a potravu, může zabraňovat záplavám, erozi půdy atd. Co z toho je funkce hlavní a vedlejší? Vše je $\checkmark$ rámci celku důležité. Tyto zásady mohou být využity při plánování aktivit $s$ dětmi, kdy jedna aktivita (prvek) uspokojuje více různých potřeb najednou. Př́kladem z výuky může být hra na schovávanou v lese. Děti si procvičují počítání (matematika), komunikační schopnosti, mají pohyb, budují vztah s prírodou a mnohé další.

Podpořit inkluzivní myšlení $v$ dětech se můžeme snažit tím, že si s nimi klademe otázky: Jak si navzájem pomáhat? Jak docílit vzájemné souhry věcí? Je něco, co bychom mohli přidat, aby celek lépe fungoval? Má každý možnost zapojit se? (Do hry, kruhu, činnosti, tř́idy, atd.)

Sám pedagog se může $v$ rámci sebereflexe své činnosti ptát: Jak uplatnit $v$ jedné výukové hodině různé aspekty učení se? Pokud je podstatné zapojit každého, jaké jsou zde vlastně možnosti např. pro vegetariány, handicapované atd. Mohou se všichni rovnocenně zapojit? I ti se speciálními potřebami? Jak může být každého důležitého cíle dosaženo různými typy aktivit?

Permakulturní princip „Využívej malých a pomalých řešení" vybízí, aby se všemu věnoval potřebný čas a dokončil se jeden krok před tím, než se přejde $k$ dalšímu. Menší rychlost při řešení věcí, malé změny mohou mít velký efekt (jsou často efektivnější a udržitelnější než ty velkolepé.). Běžnou chybou při zavádění nového, v našem případě při zavádění permakultury do nového prostředí, je snaha změnit či zavést mnoho nových věcí najednou. Praktický permakulturní design však má obsahovat realistický časový plán začínající prvním dosažitelným krokem. Poté přichází další. Jestliže si dáme pozor, abychom ve výuce postupovali vždy jen o jeden krok z místa, na němž se děti nacházejí, a nedělali př́liš velké skoky $v$ učivu, pomůže nám to zapojit do výuky každého žáka. 
V kontextu inkluze nelze opomenout další z permakulturních principů „Využívej rozmanitosti a važ si ji". $\vee$ prírodě i u lidí nacházíme různost forem, funkcí, potřeb a interakcí. Je spíše "nešvarem" uvádět věci a lidi do konformní, monotónní, standardizované a podobné formy. Permakultura chce dětem ukázat, že v celku prírody to tak není, že její udržitelnost a funkčnost a také dynamiku zajištujue právě ona různorodost.

Formou rozumíme viditelný tvar, vzhled; funkcí to, jak tyto vlastnosti působí. Diverzita je důležitý pojem pro permakulturu a pro ekosystémy vůbec. Diverzita existuje jednak mezi druhy, jednak v rámci druhů (vnitrodruhová) - tu představují např. odrůdy rostlin či plemena zviŕat, která byla vyšlechtěna, aby se hodila do místních podmínek. Tato diverzita je potřebná, aby život prospíval, byl odolný ke škůdcům a chorobám a přizpůsoboval se změnám. Pro zdravý a odolný systém jsou potřeba všechny ( $v$ něm) existující druhy a odrůdy rostlin, zviŕat, bakterií, hub a lidí. Proto čím více těchto druhů (lidí, zviŕat i rostlin) se nachází v jistém místě, či systému, tím zdravější vše v systému bude.

Pro permakulturu je naprosto nezbytné, aby děti zažily různost. Inkluze je tedy žádoucí již ze samé podstaty permakultury. Je důležitá pro funkčnost systému (společnosti, ekosystému) a ne naopak, jak je $v$ běžné praxi vnímáno - kdy se soudí, že je zátěží pro systém a je třeba ji minimalizovat či odsunout do zvláštních "speciálních lokalit" co nejdál z centra systému, na okraj. Vyloučit různost neznamená pro permakulturu podpůrný krok směrem k funkčnosti systému. Právě naopak - je to krok proti jeho vývoji, udržitelnosti a funkční existenci. Permakultura má zcela opačnou optiku, než běžný pohled. Nevylučovat, začleňovat, inspirovat se růzností, diverzitou! $\mathrm{K}$ tomu, aby děti zakusily různost může sloužit široké spektrum přiležitostí. Od setkávání či hraní si s dětmi jiných kultur, věku, handicapovanými, nebo trávení času se seniory. Pedagog má pomoci dětem najít a ocenit to, co mají různí lidé, různé druhy, plemena či odrůdy společného, stejně tak jako tak co mají rozdílného. Povzbudit děti $v$ tom, že i když je daná věc, osoba odlišná, přesto je hodnotná, že vše může přispívat svým vlastním způsobem (např. plevel považovaný často za nehodnotný, je prospěšný tím, že dodává důležité živiny, zlepšuje půdu pro jiné rostliny a také ji kryje proti vysychání půdy. Například pampelišky zúrodňují půdu svými dlouhými a vitálními kořeny, kypř́ tak tvrdou zem. Děti se mohou učit vážit si různých rostlin, včetně plevelů, nejen těch vzácných, ušlechtilých. Tato zkušenost a prístup jim pomůže změnit optiku a poté se jim promítne i do dalších oblastí života. $V$ praxi můžeme s dětmi například zkoumat, kolik druhů je možné $v$ dané lokalitě nalézt (at́ už obratlovců, hmyzu, rostlin...). Zamýšlet se nad tím, proč je důležité, aby na nějakém místě žilo mnoho různých druhů, prvků (at́ už lidí, zvířat, rostlin, zájmů, zvyků).

Sám pedagog si poté může $v$ rámci sebereflexe klást otázky: Jak mohu povzbudit děti s různými schopnostmi, aby se zapojily a měli jistotu, že si jich vážíme? Jak zapojit osoby různého věku, pohlaví, kultury? Jak můžeme do programu zařadit různorodé vzdělávací př́stupy (diverzita ve vzdělávání) a holistické aktivity, abychom zajistili naplnění odlišných potřeb dětí, jakými jsou hra, pohyb, relaxace, porozumění apod.?

Inspirující je také další princip „Využívej krajů a važ si okrajových systémů". Hovoři mimo jiné o tom, že někdy se to nejzajímavější odehrává v místě, kde se potkávají dvě různá prostředí. Takovému místu se říká rozhraní nebo okraj. Je to místo, kde jedno končí a druhé začíná. $V$ těchto rozhraních se dějí nové věci a vyznačují se často větším počtem druhů, které se na tomto území nachází. Např. v přírodě jsou místa s největší rozmanitostí druhů na rozmezích mezi různými prostředími, jak je ústí řeky do moře, kde se střetává slaná a sladká voda, i vzduch, půda a písek. Tato místa jsou tak rozmanitá proto, že naplňují všechny potřeby druhů, které vyžadují jen jedno z těchto prostředí, ale i těch druhů, které jich vyžadují více. I v učení existují rozhraní - rozhraní mezi známým a neznámým, mezi lidmi různých dovedností - která mohou být obohacující. 
Rozhraní existuje i na pomezí věku, kde se stýkají starší děti s mladšími. A zde se nachází také další zajímavý způsob, který Ize využít. Dobrým prostředkem, jak u dětí rozvíjen schopnost spolupráce a zároveň předcházet tomu, aby ti, kdo potřebují více času, zůstali pozadu, je ( $v$ permakultuře velmi oblíbené) vrstevnické učení - učení se od spolužáků. Zajímavým rozhraním mezi třídou a širším světem je školní hřiště. $V$ mnoha zemích může pedagog vzít celou třídu na hřiště, aniž by potřeboval s sebou kolegu nebo povolení, které by bylo nutné k opuštění areálu školy. Proto je vytváření rozmanitých nevšedních prostorů, např́klad zahrad, dobré pro praktické vyučování mimo budovu školy. Venkovní výuka zvyšuje interakci mezi dětmi, maximalizuje „okrajový efekt", zlepšuje kontakt mezi dítětem a př́rodou. Inspiraci, jak takový prostor vytvořit, najdeme např. v knize Outdoor Classrooms (Nuttall a Millington 2008).

$\mathrm{Na}$ "okrajích společnosti" je mnoho dětí, které mají různé zkušenosti z domova, ze školy či odjinud. Např. děti vzdělávané doma; děti, které přišly o jednoho z rodičů; děti uprchlíků; děti v pěstounské péči; děti bez domova; děti mluvící jiným jazykem. Pro permakulturu je žádoucí cenit si zkušeností těchto menšin, hledat v nich inspiraci pro svůj život, a hlavně si dávat pozor, abychom se vyhnuli předsudkům či stereotypům.

Učitel si v rámci sebereflexe může klást otázky: Který okraj nebo rozhraní můžeme prozkoumat či odhalit? Jakou př́rodu můžeme nalézt právě zde, na hřišti, ve škole, v parku? Děti pak může podporovat dotazy: Kde v přírodě vidíš rozhraní? Co se tam děje? Kde můžeme vidět nejvíc druhů?

V praxi využívá permakultura k učení často přírodní zahrady. Také, prozatím bohužel ve výrazně menší míre, i zvířata. V zahradě se dá ukázat, jak jsou všechny druhy, at již rostlin nebo živočichů, důležité pro funkčnost celého systému zahrady. Nízké půdokryvné rostliny, nevzhledné lišejníky, stejně jako vysoké ozdobné květiny či keře. Každý druh má své nezastupitelné místo $v$ rámci systému, plní určitou funkci. Často se i doplňuje se svým protikladem, kooperuje s jinými druhy na základě symbiózy. Esteticky výrazná květina, stejně jako pro nás nevzhledné bakterie na jejích kořenech.

Při začtení se do permakulturní literatury nás jistě napadne ještě mnoho dalších souvislostí s inkluzivním a otevřeným přístupem ke světu, s výchovou a vzděláváním. Předložený text je pouhou inspirací a podnětem $k$ zamyšlení $v$ rámci daného tématu.

\section{Doporučená literatura:}

- Alderslowe, L., Amus, G., Deshaies, D. (2018). Péče o zemi, péče o lidi a spravedlivé dělení ve vzdělávání. Praha.

- Bartoňová, M., Vítková, M. (2016). Strategie vzdělávání žáků se speciálními vzdělávacími potřebami $v$ inkluzivním prostředí základní školy. Texty $k$ distančnímu vzdělávání. 1. vydání. Brno: Paido Brno.

- Bartoňová, M., Vítková, M. (2016). Vzdělávání se zaměřením na inkluzivní didaktiku a vyučování žáků se speciálními vzdělávacími potřebami ve škole hlavního vzdělávacího proudu. 3. dotisk 1. vyd. Brno: Masarykova univerzita.

- Fukuoka, M. (1998). Revoluce jednej slamky. AlterNativa.

- Grandinová, T. (2016). Jiní ... Ne horší. Praha.

- Grandinová, T. (2015). Jak to vidím já. Osobní pohled na autismus a Aspergův syndrom. Praha 
- Holmgren, D. (2006). Permakultura: principy a cesty nad rámec trvalé udržitelnosti. Svojanov: PermaLot.

- Janoušková, S., Kukal, P. (2008). Environmentální výchova v př́bězích. Praha: Fortuna. Dostupné také z: http://www.digitalniknihovna.cz/mzk/uuid/uuid:29832e905dcd-11e5-bc53-005056827e52

- Hájková, V., Strnadová, I. (2010). Inkluzivní vzdělávání: teorie a praxe. Vydání 1. Praha: Grada, 2010.

- Lechta, V. (2010). Základy inkluzivní pedagogiky. Praha: Portál.

- Mollison, B. (2012). Úvod do Permakultury. Brdárka (Slovensko): Alter Nativa.

- Maser, Ch. (1996). Přeměněný les. Abies.

- Krajhanzl, A. (2014). Psychologie vztahu k životnímu prostředí. Brno: Lipka.

- Lojdová, K. a kol. (2018). Pedagogická orientace. „Být jiný v české základní škole". Vol 28, No 2.

- Máchal, A., Nováčková, H., Sobotová, L. a kol. (2012). Úvod do environmentální výchovy a globálního rozvojového vzdělávání. Brno: Lipka.

- Nátr, L. (2005). Rozvoj trvale neudržitelný. Vyd. 1. Praha: Univerzita Karlova v Praze.

- Pike, G., Selby, D. (1994). Globální výchova. Praha: Grada.

- Whitefield, P. (1996). Permakultura v kostce. Praha: Synergie.

- Sartoriusová, G. (2002). Rostliny si pomáhají. Granit s.r.o.

- Šula, B. (2002). Pohádky o květinách. Praha: Junák - svaz skautů a skautek, Tiskové a distribuční centrum.

- Svoboda, J. (2009). Kompletní návod k vytvoření ekozahrady a rodového statku. Praha: Smart Press.

- Vladislav, J. (2013). Proměny: legendy o stromech a květinách. Praha: Malvern.

- Wohlleben, P. (2016). Tajný život stromů. Rájec-Jestřebí. 